ASTHMA

\title{
Increase in diagnosed asthma but not in symptoms in the European Community Respiratory Health Survey
}

\author{
S Chinn, D Jarvis, P Burney, C Luczynska, U Ackermann-Liebrich, J M Antó, I Cerveri, R de Marco, \\ T Gislason, J Heinrich, C Janson, N Künzli, B Leynaert, F Neukirch, J Schouten, J Sunyer, C Svanes, \\ $P$ Vermeire, $M$ Wist
}

Thorax 2004;59:646-651. doi: 10.1136/thx.2004.021642

See end of article for authors' affiliations

Correspondence to: Professor S Chinn, Department of Public Health Sciences, King's College London, London SEl 3QD, UK: sue.chinn@kcl.ac.uk

Received 16 January 2004 Accepted 30 March 2004
Background: Information on the epidemiology of asthma in relation to age is limited and hampered by reporting error. To determine the change in the prevalence of asthma with age in young adults we analysed longitudinal data from the European Community Respiratory Health Survey.

Methods: A self-administered questionnaire was completed by 11168 randomly selected subjects in 14 countries in 1991-3 when they were aged 20-44 years and 5-11 years later from 1998 to 2003. Generalised estimating equations were used to estimate net change in wheeze, nocturnal tightness in chest, shortness of breath, coughing, asthma attacks in the last 12 months, current medication, "diagnosed" asthma, and nasal allergies.

Results: Expressed as change in status per 10 years of follow up, subjects reporting asthma attacks in the previous 12 months increased by $0.8 \%$ of the population $(95 \% \mathrm{Cl} 0.2$ to 1.4$)$ and asthma medication by $2.1 \%(95 \% \mathrm{Cl} 1.6$ to 2.6$)$, while no statistically significant net change was found in reported symptoms. Reported nasal allergies increased, especially in the youngest age group.

Conclusions: As this cohort of young adults has aged, there has been an increase in the proportion treated for asthma but not in the proportion of those reporting symptoms suggestive of asthma. Either increased use of effective treatments has led to decreased morbidity among asthmatic subjects or those with mild disease have become more likely to label themselves as asthmatic.
$\mathrm{C}$ ross sectional studies have shown a lower prevalence of asthma, ${ }^{1}$ asthma-like symptoms, ${ }^{1}$ and bronchial responsiveness ${ }^{2}$ in early adult life compared with late childhood. This finding would be expected if remission of symptoms exceeded the incidence of symptoms in older subjects or if the cumulative incidence of symptoms was greater in younger cohorts. Observation of a single cohort over time allows a detailed description of the natural history of disease with aging, with no confounding by differences in cumulative incidence between cohorts.

A comparison of data collected by longitudinal studies is hampered by the lack of a standardised methodology, with varying definitions of asthma being used, different age groups being studied, and variation in the statistical analyses adopted to generate results. Most of these studies have calculated incidence and remission rates, each of which is overestimated in the presence of reporting error. Robust external or ancillary information on the reliability of the measuring instrument is required to present unbiased estimates, ${ }^{3}{ }^{4}$ and such information is rarely available. Our knowledge and understanding of the epidemiology of asthma within populations as they age is therefore very limited.

We present results from an international longitudinal study of asthma symptoms in which all participating centres adopted a common protocol for subject recruitment and symptom measurement. We report net change in the symptoms of asthma and hay fever in the cohort, and investigate the heterogeneity of change across centres and its relation to age and sex.

\section{METHODS}

\section{Study subjects}

In ECRHS I participating centres were each selected as an area defined by pre-existing administrative boundaries with a population of at least 150000 people. ${ }^{5}$ Where possible an up to date sampling frame was used to select randomly at least 1500 men and 1500 women aged 20-44 years. In stage 1 subjects were sent a questionnaire enquiring about respiratory symptoms and attacks of asthma in the last 12 months, current use of asthma medication, and nasal allergies including hay fever. A random sample of subjects was selected to take part in stage 2. Those who had already responded to stage 1 were invited to answer a more detailed administered questionnaire and to take part in blood tests, assessment of lung function by spirometry, and airway challenge with methacholine. Participants were divided into age groups according to age at ECRHS I stage 1 (20-24 years, 25-34 years, and 35 years or older).

\section{Study design}

Most of the centres that participated in ECRHS I stage 2 have taken part in ECRHS II. $^{6}$ Participants in ECRHS I who responded to stage 2 , defined as those who provided at least data on smoking at stage 2, were eligible for ECRHS II. Only participants selected for the random sample in ECRHS I are included. Four centres (in Gemany, The Netherlands and the USA) were not able to follow up the whole of the eligible sample and selected a representative subsample. Follow up took place from 1998 to 2002.

The stage 1 questionnaire, shown in Appendix 1, was identical in the two surveys. Like ECRHS I, ECRHS II had two stages but all symptom data were taken from the stage 1 questionnaires for the two surveys.

\section{Analysis of data}

Absolute change in symptom status per year of follow up was estimated using population averaged generalised estimating equations for a binomial outcome with identity link, with 
Table 1 Response to ECRHS II stage 1 in random sample

\begin{tabular}{|c|c|c|c|c|c|c|c|}
\hline Country & Centre & $\begin{array}{l}\text { Responded to ECRHS I } \\
\text { stage } 2 / \text { target for } \\
\text { ECRHS II (where } \\
\text { different) }\end{array}$ & $\begin{array}{l}\text { Responded to } \\
\text { ECRHS II (\% of } \\
\text { target) }\end{array}$ & $\begin{array}{l}\text { Median (IQR) length of } \\
\text { follow up (years) }\end{array}$ & $\begin{array}{l}\text { Female } \\
(\%)\end{array}$ & $\begin{array}{l}\text { Mean age of } \\
\text { ECRHS I }\end{array}$ & $\begin{array}{l}\text { Mean age of } \\
\text { ECRHS II }\end{array}$ \\
\hline Iceland & Reykjavik & 563 & $445(79.0)$ & 8.38 (8.36 to 8.52$)$ & 53.9 & 33.1 & 41.7 \\
\hline Norway & Bergen & 835 & $658(78.8)$ & 9.20 (9.19 to 9.24$)$ & 50.5 & 32.0 & 41.2 \\
\hline \multirow[t]{3}{*}{ Sweden } & Umea & 552 & 459 (83.2) & $8.20(8.19$ to 8.25$)$ & 50.3 & 33.1 & 41.3 \\
\hline & Uppsala & 622 & $513(82.5)$ & $8.19(8.16$ to 8.23$)$ & 52.0 & 32.4 & 40.6 \\
\hline & Goteborg & 682 & $548(80.4)$ & $8.17(8.16$ to 8.20$)$ & 54.2 & 32.6 & 40.8 \\
\hline Estonia & Tartu & 431 & $352(81.7)$ & $5.22(5.20$ to 5.36$)$ & 58.8 & 31.2 & 36.5 \\
\hline Denmark & Aarhus & 394 & $321(81.5)$ & 7.76 (7.76 to 7.78$)$ & 56.1 & 32.7 & 40.5 \\
\hline \multirow{2}{*}{ Belgium } & Antwerp City & 564 & 403 (71.5) & 8.59 (8.55 to 8.64$)$ & 60.3 & 32.7 & 41.3 \\
\hline & South Antwerp & 558 & $432(77.4)$ & $9.34(9.25$ to 9.42$)$ & 53.0 & 33.4 & 42.7 \\
\hline \multirow[t]{2}{*}{ Germany } & Hamburg & $1252 / 900$ & $672(74.7)$ & 9.77 (8.84 to 9.94$)$ & 50.3 & 33.7 & 43.2 \\
\hline & Erfurt & $731 / 715$ & $548(76.6)$ & $8.74(8.62$ to 8.88$)$ & 49.3 & 33.5 & 42.2 \\
\hline Netherlands & Geleen & $415 / 369$ & $258(69.9)$ & $10.91(10.89$ to 11.10$)$ & 53.9 & 34.3 & 45.3 \\
\hline \multirow[t]{3}{*}{ UK } & Caerphilly & 380 & $263(69.2)$ & $11.14(10.97$ to 11.63$)$ & 58.9 & 35.2 & 46.4 \\
\hline & Norwich & 473 & $408(86.3)$ & 7.77 (7.53 to 8.04$)$ & 59.8 & 33.3 & 41.1 \\
\hline & Ipswich & 448 & $389(86.8)$ & 7.42 (7.27 to 7.77$)$ & 56.3 & 33.3 & 40.9 \\
\hline Switzerland & Basel & $853 / 852$ & $513(60.2)$ & $10.24(10.08$ to 10.32$)$ & 52.2 & 33.4 & 43.6 \\
\hline \multirow[t]{4}{*}{ France } & Bordeaux & 544 & $167(30.7)$ & $9.64(9.40$ to 9.88$)$ & 46.1 & 32.6 & 42.2 \\
\hline & Paris & 651 & $493(75.7)$ & 8.49 (7.86 to 8.62$)$ & 54.4 & 35.6 & 44.2 \\
\hline & Grenoble & 473 & 417 (88.2) & $10.04(9.81$ to 10.26$)$ & 46.8 & 34.9 & 44.8 \\
\hline & Montpellier & 456 & $285(62.5)$ & 7.33 (6.73 to 8.38$)$ & 49.1 & 35.7 & 43.2 \\
\hline \multirow[t]{5}{*}{ Spain } & Oviedo & 357 & $310(86.8)$ & $6.86(6.66$ to 7.11$)$ & 50.6 & 33.9 & 40.8 \\
\hline & Galdakao & 486 & $429(88.3)$ & $7.02(6.82$ to 7.40$)$ & 50.3 & 31.6 & 38.7 \\
\hline & Barcelona & 392 & $314(80.1)$ & 7.28 (6.94 to 7.52$)$ & 58.9 & 32.5 & 39.8 \\
\hline & Albacete & 435 & $393(90.3)$ & $6.92(6.70$ to 7.21$)$ & 53.7 & 31.7 & 38.6 \\
\hline & Huelva & 271 & $223(82.3)$ & 6.89 (6.43 to 7.43$)$ & 52.9 & 32.3 & 39.2 \\
\hline \multirow[t]{3}{*}{ Italy } & Verona & 342 & $254(74.3)$ & 7.80 (7.75 to 8.12$)$ & 48.8 & 32.9 & 40.8 \\
\hline & Pavia & 310 & $288(92.9)$ & 7.39 (7.08 to 7.59$)$ & 48.3 & 34.4 & 41.7 \\
\hline & Turin & 244 & $176(72.1)$ & $6.94(6.72$ to 7.49$)$ & 51.1 & 33.2 & 40.4 \\
\hline USA & Portland & $731 / 380$ & $238(62.6)$ & 8.01 (7.74 to 8.17$)$ & 55.5 & 35.8 & 43.8 \\
\hline Total target & & 14679 & $11169(76.1)$ & & 52.9 & 33.3 & 41.7 \\
\hline
\end{tabular}

participants identified as the clustering factor and length of follow up as an independent variable, using Stata. ${ }^{7}$ Differences by sex or between age groups were considered statistically significant when $\mathrm{p}<0.01$. Estimates by centre were examined for heterogeneity and combined using random effects meta-analysis. ${ }^{8}$ Results are expressed as net change per 10 years of follow up.

\section{RESULTS}

Twenty nine centres carried out stage 1 of ECRHS II. The response rate was over $60 \%$ (table 1 ) in all except one centre (Bordeaux), and $75 \%$ or more in 19 centres, giving a total of
11169 participants. The length of follow up varied between centres because some centres joined ECRHS I late (Tartu) or carried out ECRHS II stage I early (particularly the Spanish centres). Hence, although the mean age between centres varied from 31.2 years (Tartu) to 35.8 years (Portland) at ECRHS I, it ranged from 36.5 years (Tartu) to 46.4 years (Caerphilly) at ECRHS II.

The net change in the prevalence of symptoms is shown in table 2, and also the prevalence at ECRHS I. The prevalence of symptoms at ECRHS II is not shown because of the variable length of follow up. The net changes in wheeze with breathlessness (Q1.1), nocturnal shortness of breath (Q3),

Table 2 Net change in asthma symptoms and medication per 10 years of follow up, estimated by generalised estimating equations and combined by random effects meta-analysis across centres

\begin{tabular}{|c|c|c|c|c|c|c|}
\hline $\begin{array}{l}\text { Question } \\
\text { (see Appendix 1) }\end{array}$ & $\begin{array}{l}\text { No of } \\
\text { centres }\end{array}$ & $\begin{array}{l}\text { No of } \\
\text { participants }\end{array}$ & $\begin{array}{l}\text { Prevalence }(\%) \text { in } \\
\text { ECRHS I in responders } \\
\text { to ECRHS II }\end{array}$ & $\begin{array}{l}\text { Change }(95 \% \mathrm{Cl}) \\
\text { in prevalence }(\%)\end{array}$ & $\begin{array}{l}\text { p value for } \\
\text { change }\end{array}$ & $\begin{array}{l}\text { p value for } \\
\text { heterogeneity }\end{array}$ \\
\hline Q1: Wheeze & 29 & 11086 & 20.3 & $-0.9(-1.9$ to 0.2$)$ & 0.122 & 0.129 \\
\hline $\begin{array}{l}\text { Q1.1: Wheeze with } \\
\text { breathlessness }\end{array}$ & 29 & 10991 & 9.9 & $0.3(-0.3$ to 0.9$)$ & 0.367 & 0.491 \\
\hline $\begin{array}{l}\text { Q1.2: Wheeze without } \\
\text { a cold }\end{array}$ & 29 & 11029 & 12.2 & $0.2(-0.8$ to 1.1$)$ & 0.767 & 0.029 \\
\hline $\begin{array}{l}\text { Q2: Woken with chest } \\
\text { tightness }\end{array}$ & 23 & 9093 & 12.8 & $0.0(-1.3$ to 1.3$)$ & 0.967 & 0.003 \\
\hline $\begin{array}{l}\text { Q3: Woken with shortness } \\
\text { of breath }\end{array}$ & 28 & 10746 & 5.8 & $0.2(-0.4$ to 0.8$)$ & 0.449 & 0.424 \\
\hline $\begin{array}{l}\text { Q4: Woken by attack of } \\
\text { coughing }\end{array}$ & 21 & 8686 & 27.8 & $-1.2(-2.7$ to 0.3$)$ & 0.122 & 0.090 \\
\hline Q5: Attack of asthma & 29 & 11064 & 3.4 & $0.8(0.2$ to 1.4$)$ & 0.011 & 0.006 \\
\hline Q6: Current medication & 29 & 11083 & 3.7 & 2.1 (1.6 to 2.6$)$ & $<0.001$ & 0.286 \\
\hline $\begin{array}{l}\text { Q5 or Q6*: "Diagnosed } \\
\text { asthma" }\end{array}$ & 29 & 11017 & 4.9 & $2.2(1.6$ to 2.9$)$ & $<0.001$ & 0.037 \\
\hline Q7: Nasal allergies & 23 & 8955 & 25.0 & 3.7 (2.8 to 4.5$)$ & $<0.001$ & 0.522 \\
\hline
\end{tabular}




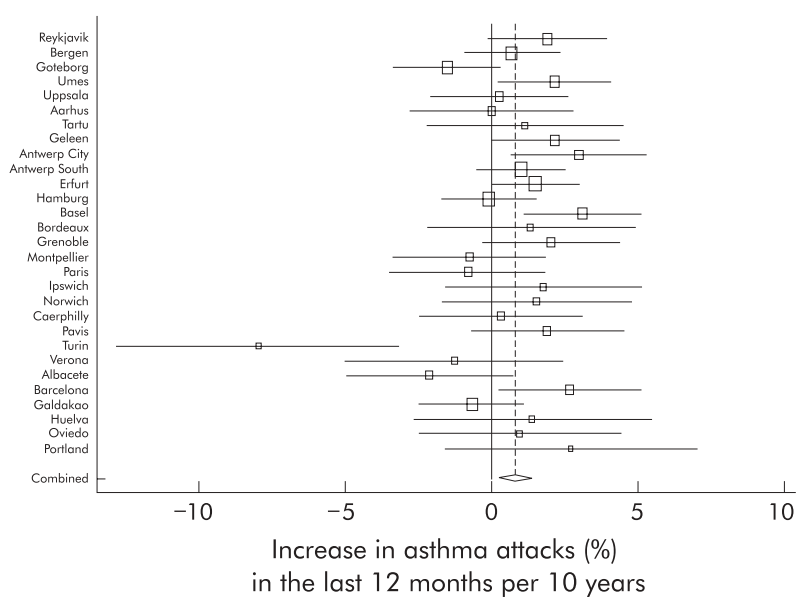

Figure 1 Net change in asthma attacks in last 12 months (with 95\% confidence interval) by centre. The area of each square is proportional to the reciprocal of the variance of the estimate for the centre. The combined random effects estimate is shown by the dashed line, the diamond having the width of its $95 \%$ confidence interval.

and nocturnal coughing (Q4) were not statistically significant $(p>0.1)$. No heterogeneity between centres in any of these outcomes was detected $(\mathrm{p}>0.05)$.

There was no evidence for any overall net change in nocturnal tightness in the chest (Q2), but net change varied between centres $(p=0.003)$ with some showing a net increase and others a net decrease. There was no overall net change in wheeze without a cold (Q1.2) but there was weak evidence for heterogeneity $(p=0.029)$.

Overall, there was an increase in the prevalence of asthma attacks in the last 12 months (Q5) $(\mathrm{p}=0.011)$. The net changes were not consistent between centres (heterogeneity $\mathrm{p}=0.006)$. This was largely, but not entirely, due to a decrease in Turin (fig 1). Including Turin, there was an overall net increase of $0.8 \%$ in the population reporting attacks of asthma (95\% CI 0.2 to 1.4 ), table 2 . There was a net increase of $2.1 \%$ (95\% CI 1.6 to 2.6 ) of the population taking medication for asthma (Q6) which did not show heterogeneity between centres $(p=0.29)$. When the responses to these two questions were combined ("diagnosed asthma"), the net increase was $2.2 \%$ (95\% CI 1.6 to 2.9$)$. Reported "nasal allergies including hay fever" (Q7) showed a net increase $(\mathrm{p}<0.001)$; no heterogeneity was detected between centres.
Table 3 shows the net change for men and women separately. There was weak evidence for a greater change in "diagnosed asthma" in women than in men $(\mathrm{p}=0.041)$ but, in view of the large number of comparisons and chosen criterion for significance, this may be a chance finding. No other difference in net change was close to statistical significance. In table 4 the results are stratified by age group. There was strong evidence for a difference in net change in reported "nasal allergies including hay fever" by age $(p=0.005)$, with the group aged $20-24$ years having a greater net increase than the older groups. There was weak evidence for a difference in nocturnal chest tightness (Q2, $\mathrm{p}=0.025$ ) with a greater net increase in the youngest age group.

There was little net change in "untreated asthma" (those reporting asthma attacks but no use of medication), a net increase of $0.2 \%(95 \% \mathrm{CI}-0.1$ to 0.5$)$ per 10 years $(\mathrm{p}=0.26)$, although there was some evidence $(\mathrm{p}=0.012)$ for an increase in women $(0.6 \%(95 \%$ CI 0.1 to 1.0$)$ per 10 years $)$ but not in men $(-0.3 \%$ ( $95 \%$ CI -0.7 to 0.2$)$.

\section{DISCUSSION}

This first multicentre international comparison has shown net increases in reported asthma attacks and use of asthma medication in a cohort of young adults studied an average of eight years apart during the 1990s. However, there was no corresponding change in the 12 month period prevalence of wheeze, chest tightness, or waking with breathlessness or with cough, each of which are symptoms that clinicians would recognise as being related to asthma. An increase in reported nasal allergies was observed that was independent of sex but was greater in the youngest age group.

The assessment of symptoms in epidemiological studies and, to a lesser degree, in the clinical setting is not free from measurement error.' In longitudinal studies this error at baseline and follow up leads to biased estimates of incidence or remission. For this reason we reported the net change in symptom status in the ECRHS as a less misleading description of natural history, even though clinicians may prefer to see information that indicates the rate at which previously disease free subjects become symptomatic (incidence) and the rate at which diseased people become asymptomatic (remission). Our results clearly indicate that, while there was no evidence for either an increase or decrease in the proportion of subjects reporting symptoms suggestive of asthma, there are increases in the proportion of participants reporting an asthma attack in the previous 12 months and

Table 3 Net change in asthma symptoms and medication per 10 years of follow up by sex, estimated by generalised estimating equations

\begin{tabular}{|c|c|c|c|c|c|c|c|}
\hline \multirow[b]{2}{*}{$\begin{array}{l}\text { Question } \\
\text { (see Appendix 1) }\end{array}$} & \multicolumn{3}{|l|}{ Men } & \multicolumn{3}{|l|}{ Women } & \multirow[b]{2}{*}{$\begin{array}{l}\text { p value for } \\
\text { difference } \\
\text { between men } \\
\text { and women }\end{array}$} \\
\hline & $\begin{array}{l}\text { Prevalence (\%) } \\
\text { in ECRHS I in } \\
\text { responders } \\
\text { to ECRHS II }\end{array}$ & $\begin{array}{l}\text { Change }(95 \% \mathrm{Cl}) \text { in } \\
\text { prevalence }(\%)\end{array}$ & $\begin{array}{l}\text { p value for } \\
\text { change }\end{array}$ & $\begin{array}{l}\text { Prevalence (\%) } \\
\text { in ECRHS I in } \\
\text { responders } \\
\text { to ECRHS II }\end{array}$ & $\begin{array}{l}\text { Change }(95 \% \mathrm{Cl}) \text { in } \\
\text { prevalence }(\%)\end{array}$ & $\begin{array}{l}\text { p value for } \\
\text { change }\end{array}$ & \\
\hline Q1 & 21.1 & $-0.3(-2.1$ to 1.4$)$ & 0.694 & 19.6 & $-1.2(-2.8$ to 0.3$)$ & 0.126 & 0.353 \\
\hline Q1.1 & 9.5 & $0.7(-0.4$ to 1.7$)$ & 0.210 & 10.2 & $-0.1(-1.0$ to 0.8$)$ & 0.825 & 0.155 \\
\hline Q1.2 & 13.3 & $0.6(-1.0$ to 2.1$)$ & 0.745 & 11.3 & $-0.3(-1.6$ to 1.0$)$ & 0.681 & 0.393 \\
\hline Q2 & 10.8 & $0.8(-0.7$ to 2.2$)$ & 0.289 & 14.6 & $-0.5(-2.0$ to 1.1$)$ & 0.564 & 0.246 \\
\hline Q3 & 5.2 & $-0.1(-0.9$ to 0.7$)$ & 0.800 & 6.3 & $0.3(-0.6$ to 1.2$)$ & 0.489 & 0.687 \\
\hline Q4 & 20.9 & $-0.1(-0.03$ to 2.6$)$ & 0.939 & 33.9 & $-2.3(-4.2$ to -0.5$)$ & 0.011 & 0.120 \\
\hline Q5 & 3.1 & $0.5(-0.1$ to 1.2$)$ & 0.094 & 3.6 & $0.9(0.2$ to 1.6$)$ & 0.011 & 0.201 \\
\hline Q6 & 3.3 & $1.9(1.1$ to 2.7$)$ & $<0.001$ & 4.0 & 2.5 (1.8 to 3.2$)$ & $<0.001$ & 0.525 \\
\hline Q5 or Q6* & 4.7 & $1.8(1.1$ to 2.6$)$ & $<0.001$ & 5.2 & 2.4 (1.6 to 3.3$)$ & $<0.001$ & 0.041 \\
\hline Q7 & 24.1 & 3.4 (2.0 to 4.8$)$ & $<0.001$ & 25.8 & $3.7(1.7$ to 5.7$)$ & $<0.001$ & 0.806 \\
\hline
\end{tabular}




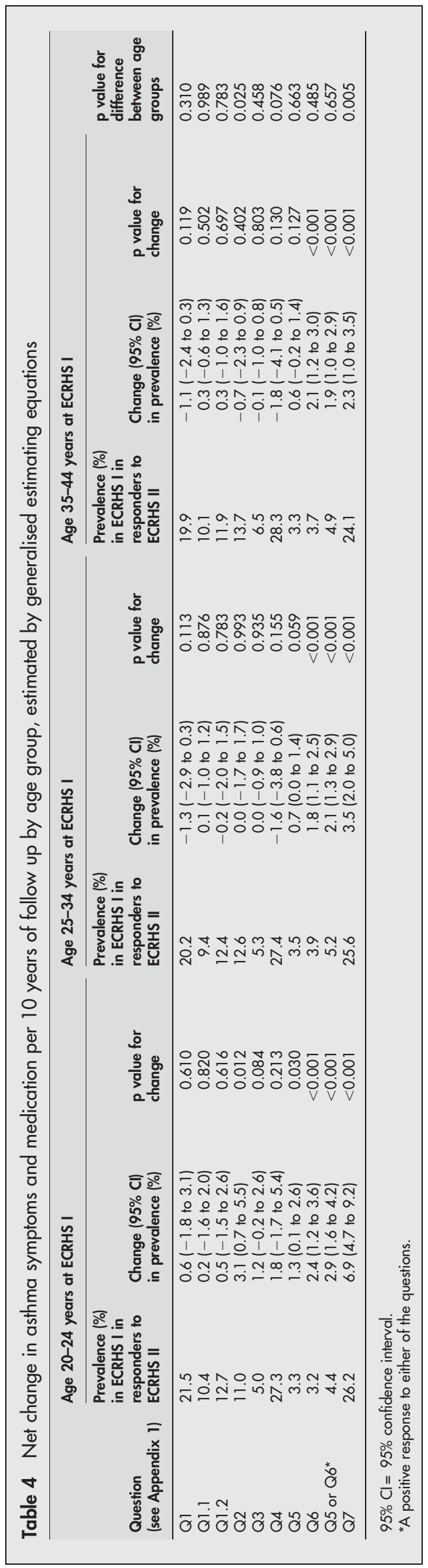

large increases in the use of medication for asthma. This pattern was observed in most but not all centres.

Although there was some evidence of participation bias, we do not think this explains our findings. Looking at responders to ECRHS II as a whole, there was no evidence of greater participation in ECRHS II by those reporting asthma attacks in ECRHS I. The prevalence of asthma attacks at ECRHS I in those selected for the random sample, but not participating in ECRHS II, was $3.4 \%$ as in responders (table 2). Examination of this centre by centre showed that, in Montpellier, Paris and Turin, responders to ECRHS II reported significantly more asthma attacks in ECRHS I than non-responders $(6.0 \% \vee 3.3 \%, 6.1 \% \vee 3.6 \%, 8.0 \% \vee 3.5 \%$, respectively) and in Geleen significantly less (0.8\% $v 3.2 \%)$. As shown in fig l, Turin is an outlier in respect of change in "asthma", showing a net decrease of $8.0 \%$ in "asthma" compared with an overall increase of $0.8 \%$, but it is unlikely that this large deviation is explained by the difference in participation.

The observed changes might be expected if at follow up subjects with disease were more likely to interpret and report their symptoms as "asthma attacks" and to be treated with effective asthma therapies, or if changes in diagnostic threshold have led to people with mild disease being more likely to be diagnosed and treated for asthma. This may have occurred because the cohort was older (aging effects) or because there were substantial changes in the diagnosis and management of asthma in the communities during the 1990s (period effects), or because of a combination of both aging and period effects.

Health service consultation rates are in general higher in older age groups and, even if the primary reason for a consultation is unrelated to respiratory symptoms, it may lead to increased opportunities for physicians to assess respiratory status and diagnose asthma. Alternatively, as people age they may be less likely to tolerate symptoms and more likely to seek diagnosis and treatment for relatively mild disease. There is some work to suggest that this is not the case and that perception of bronchoconstriction decreases with age. ${ }^{10}$ However, this hypothesis clearly warrants further investigation and, within the ECRHS II, information has been collected on markers of disease severity and on types and dosages of medication used from subjects who agreed to take part in an extended interview. These data are not available for all the subjects included in this analysis but information on an additional non-random sample of subjects symptomatic at baseline will be available.

Since the 1980s doctors have been encouraged to diagnose wheezy illness as asthma and to treat it. ${ }^{11}$ Some repeated cross sectional surveys have shown that the prevalence of reported "asthma" has increased more rapidly than the increase in reported symptoms. ${ }^{12-14}$ Two cross sectional studies of adults aged 20-44 years had a design the same as or close to that of ECRHS I. One of these found no change in the prevalence of asthma attacks but a decrease in shortness of breath, ${ }^{15}$ while the other showed varying increases in reported symptoms and diagnosed asthma but a decrease in bronchial responsiveness. ${ }^{16}$ A cohort study which also reported net change found greater increases in symptoms (especially wheeze) than in doctor diagnosed asthma, although participants were aged up to 70 years. ${ }^{17}$

While our method of analysis precludes estimation of remission and incidence separately, we are able to identify differences in change between subgroups. Within our cohort there was no evidence of differences in asthma symptoms, asthma diagnosis, or asthma treatment between men and women or between different age groups. Much of the reported literature has suggested an increased "incidence" in adult women compared with men, ${ }^{18-21}$ and there was weak 
evidence of a greater net change in "diagnosed asthma" in women $(p=0.041)$ although not in asthma attacks or medication alone.

We have shown that there is a greater net increase in reported nasal allergies in the youngest age group than in the other age groups. In a single longitudinal study it is not possible to be certain whether such an observation is explained by biological changes occurring at particular ages or by factors occurring earlier in life that make this younger cohort more susceptible to the development of disease. However, the differences in net change between age groups-with the youngest age group showing three times that of the oldest age group-are large in relation to the differences in prevalence at baseline $(26 \%$ in the youngest age group and $24 \%$ in the oldest age group), which suggests a possible cohort effect on incidence. Two longitudinal studies each found an age related increase in positive skin prick tests over time with the greatest increase in young adults, ${ }^{22}{ }^{23}$ but one study showed no corresponding age related change in total IgE. ${ }^{22}$ No other age related association with change was detected in the ECRHS.

In summary, we have shown that populations of young adults reported greater use of asthma medication and more asthma attacks as they aged during the 1990s. Surprisingly, these same populations reported no associated change in respiratory symptoms suggestive of asthma. This mismatch may be explained by age or period effects in the diagnosis and management of asthma that has led to increased labelling of mild disease or by increased use of medication in these populations. Increases in hay fever and nasal allergies were also observed with much greater changes being seen in the younger cohorts.

\section{Authors' affiliations}

S Chinn, D Jarvis, P Burney, C Luczynska, Department of Public Health Sciences, King's College London, London SEI 3QD, UK

U Ackermann-Liebrich, N Künzli, Institute of Social and Preventive Medicine, University of Basel, CH 4051 Basel, Switzerland

J M Antó, J Sunyer, Medical Research Institute (IMIM), Universitat Pompeu Fabra (UPF), 08009 Barcelona, Spain

I Cerveri, Division of Respiratory Diseases, IRCCS "San Matteo" Hospital, University of Pavia, 27100 Pavia, Italy

R de Marco, University of Verona, Department of Medicine and Public Health, Division of Epidemiology and Statistics, 8-37134 Verona, Italy T Gislason, Department of Allergy, Respiratory Medicine and Sleep, University Hospital (E7), 105 Reykjavik, Iceland

J Heinrich, M Wist, Institute of Epidemiology, GSF-National Research Center for Environment and Health, D-85764 Neuherberg, Germany C Janson, Respiratory Medicine and Allergology, University of Uppsala, 75185 Uppsala, Sweden

N Künzli, Keck School of Medicine, University of Southern California, Los Angeles, California 90089-9013, USA

B Leynaert, F Neukirch, INSERM-The French Institute of Health and Medical Research, Unit 408-Epidemiology, Faculty of Medicine X Bichat, 75870 Paris Cedex 18, France

J Schouten, Department of Health Sciences, University of Groningen, 9713 AV Groningen, The Netherlands

C Svanes, Department of Medicine, Haraldsplass Hospital, 5009 Bergen, Norway

P Vermeire, University of Antwerp (Campus Drie Eiken), B-2610 Antwerp, Belgium

The coordination of ECRHS II was supported by the European Commission as part of their Quality of Life programme.

The following bodies funded the local studies in ECRHS II:

Aarhus: Danish Lung Association; Albacete: Fondo de Investigaciones Santarias (FIS) (grant code: 97/0035-01, 99/0034-01 and 99/003402), Hospital Universitario de Albacete, Consejeria de Sanidad; Antwerp: FWO (Fund for Scientific Research)-Flanders Belgium (grant code: G.0402.00), University of Antwerp, Flemish Health Ministry; Barcelona: SEPAR, Public Health Service lgrant code: R01 HL62633-
01), Fondo de Investigaciones Santarias (FIS) (grant code: 97/0035-01, 99/0034-01 and 99/0034-02) CIRIT (grant code: 1999SGR 00241)); Basel: Swiss National Science Foundation, Swiss Federal Office for Education \& Science, Swiss National Accident Insurance Fund (SUVA); Bergen: Norwegian Research Council, Norwegian Asthma \& Allergy Association (NAAF), Glaxo Wellcome AS, Norway Research Fund; Bordeaux: Institut Pneumologique d'Aquitaine; Erfurt: GSFNational Research Centre for Environment \& Health, Deutsche Forschungsgemeinschaft (DFG) (grant code FR 1526/1-1); Galdakao: Basque Health Department; Goteborg: Swedish Heart Lung Foundation, Swedish Foundation for Health Care Sciences \& Allergy Research, Swedish Asthma \& Allergy Foundation, Swedish Cancer \& Allergy Foundation; Grenoble: Programme Hospitalier de Recherche Clinique-DRC de Grenoble 2000 no. 2610, Ministry of Health, Direction de la Recherche Clinique, Ministere de l'Emploi et de la Solidarite, Direction Generale de la Sante, CHU de Grenoble, Comite des Maladies Respiratoires de I'Isere; Hamburg: GSFNational Research Centre for Environment \& Health, Deutsche Forschungsgemeinschaft (DFG) (grant code MA 711/4-1); lpswich and Norwich: National Asthma Campaign (UK); Huelva: Fondo de Investigaciones Santarias (FIS) (grant code: 97/0035-01, 99/003401 and 99/0034-02); Melbourne: National Health and Medical Research Council of Australia; Montpellier: Programme Hospitalier de Recherche Clinique-DRC de Grenoble 2000 no. 2610, Ministry of Health, Direction de la Recherche Clinique, CHU de Grenoble, Ministere de l'Emploi et de la Solidarite, Direction Generale de la Sante, Aventis (France), Direction Régionale des Affaires Sanitaires et Sociales Languedoc-Roussillon; Oviedo: Fondo de Investigaciones Santarias (FIS) (grant code: $97 / 0035-01,99 / 0034-01$ and 99/ 0034-02); Paris: Ministere de l'Emploi et de la Solidarite, Direction Generale de la Sante, UCB-Pharma (France), Aventis (France), Glaxo France, Programme Hospitalier de Recherche Clinique-DRC de Grenoble 2000 no. 2610, Ministry of Health, Direction de la Recherche Clinique, CHU de Grenoble; Pavia: Glaxo-SmithKline Italy, Italian Ministry of University and Scientific and Technological Research (MURST), Local University Funding for research 1998 and 1999 (Pavia, Italy); Portland: American Lung Association of Oregon, Northwest Health Foundation, Collins Foundation, Merck Pharmaceutical; Reykjavik: Icelandic Research Council, Icelandic University Hospital Fund; Tartu: Estonian Science Foundation; Turin: ASL 4 Regione Piemonte (ltaly), AO CTO/ICORMA Regione Piemonte (Italy), Ministero dell'Università e della Ricerca Scientifica (Italy), Glaxo Wellcome spa (Verona, Italy); Umeå: Swedish Heart Lung Foundation, Swedish Foundation for Health Care Sciences \& Allergy Research, Swedish Asthma \& Allergy Foundation, Swedish Cancer \& Allergy Foundation; Uppsala: Swedish Heart Lung Foundation, Swedish Foundation for Health Care Sciences \& Allergy Research, Swedish Asthma \& Allergy Foundation, Swedish Cancer \& Allergy Foundation; Verona: University of Verona; Italian Ministry of University and Scientific and Technological Research (MURST); Glaxo-SmithKline Italy.

Financial support for ECRHS I for centres in ECRHS II: Belgian Science Policy Office, National Fund for Scientific Research; Ministère de la Santé, Glaxo France, Insitut Pneumologique d'Aquitaine, Contrat de Plan Etat-Région Languedoc-Rousillon, CNMATS, CNMRT (90MR/10, 91AF/6), Ministre delegué de la santé, RNSP, France; GSF, and the Bundesminister für Forschung und Technologie, Bonn, Germany; Ministero dell'Universitò e della Ricerca Scientifica e Tecnologica, CNR, Regione Veneto grant RSF n. 381/05.93, Italy; Norwegian Research Council project no. 101422/310; Dutch Ministry of Wellbeing, Public Health and Culture, Netherlands; Ministero Sanidad y Consumo FIS (grants \#91/0016060/00E-05E and \#93/0393), and grants from Hospital General de Albacete, Hospital General Juan Ramón Jiménenz, Consejeria de Sanidad Principado de Asturias, Spain; The Swedish Medical Research Council, the Swedish Heart Lung Foundation, the Swedish Association against Asthma and Allergy; Swiss National Science Foundation grant 4026-28099; National Asthma Campaign, British Lung Foundation, Department of Health, South Thames Regional Health Authority, UK; United States Department of Health, Education and Welfare Public Health Service Igrant \#2 S07 RR05521-28).

Project Leader: P Burney; Statistician: S Chinn; Principal Investigator: D Jarvis; Project Coordinator: J Knox; Principal Investigator: C Luczynska; Assistant Statistician: J Potts; Data Manager: S Arinze.

Steering Committee for ECRHS II: Professor J M Antó, Institut Municipal d'Investigació Mèdica (IMIM-IMAS), Universitat Pompeu Fabra (UPF); Professor P Burney, King's College London (Project Leader); Dr I Cerveri, 
University of Pavia; Professor S Chinn, King's College London; Professor $\mathrm{R}$ de Marco, University of Verona; Dr T Gislason, Iceland University Hospital; Dr J Heinrich, GSF-Institute of Epidemiology; Assoc Professor C Janson, Uppsala University; Dr D Jarvis, King's College London; Miss J Knox, King's College London; Dr N Künzli, University of Basel and University of Southern California Los Angeles; Dr B Leynaert, Institut National de la Santé et de la Recherche Médicale (INSERM); Dr C Luczynska, King's College London; Dr F Neukirch, Institut National de la Santé et de la Recherche Médicale (INSERM); Dr J Schouten, University of Groningen; Dr J Sunyer, Institut Municipal d'Investigació Mèdica (IMIM-IMAS), Universitat Pompeu Fabra (UPF); Dr C Svanes, University of Bergen; Professor P Vermeire, University of Antwerp; Dr M Wist, GSF-Institute of Epidemiology.

Principal Investigators and Senior Scientific Team: Belgium: South Antwerp \& Antwerp City (P Vermeire, J Weyler, M Van Sprundel, V Nelen); Denmark: Aarhus (EJ Jensen); Estonia: Tartu (R Jogi, A Soon); France: Paris (F Neukirch, B Leynaert, R Liard, M Zureik), Grenoble (I Pin, J Ferran-Quentin); Germany: Erfurt (J Heinrich, M Wjst, C Frye, I Meyer); Iceland: Reykjavik (T Gislason, E Bjornsson, D Gislason, T Blondal, A Karlsdottir); Italy: Turin (M Bugiani, P Piccioni, E Caria, A Carosso, E Migliore, G Castiglioni), Verona (R de Marco, G Verlato, E Zanolin, S Accordini, A Poli, V Lo Cascio, M Ferrari), Pavia (A Marinoni, S Villani, M Ponzio, F Frigerio, M Comelli, M Grassi, I Cerveri, A Corsico); Netherlands: Groningen \& Geleen (J Schouten, M Kerkhof); Norway: Bergen (A Gulsvik, E Omenaas, C Svanes, B Laerum); Spain: Barcelona (JM Antó, J Sunyer, M Kogevinas, JP Zock, X Basagana, A Jaen, F Burgos), Huelva (J Maldonado, A Pereira, JL Sanchez), Albacete (J Martinez-Moratalla Rovira, E Almar), Galdakao (N Muniozguren, I Urritia), Oviedo (F Payo); Sweden: Uppsala (C Janson, G Boman, D Norback, M Gunnbjornsdottir), Goteborg (K Toren, L Lillienberg, AC Olin, B Balder, A Pfeifer-Nilsson, R Sundberg), Umea (E Norrman, M Soderberg, K Franklin, B Lundback, B Forsberg, L Nystrom); Switzerland: Basel (N Künzli, B Dibbert, M Hazenkamp, M Brutsche, U Ackermann-Liebrich); UK: Norwich (D Jarvis, B Harrison), Ipswich (D Jarvis, R Hall, D Seaton).

Centres taking part at their own expense: Australia: Melbourne (M Abramson, R Woods, EH Walters, F Thien); France: Bordeaux (A Taytard, C Raherison), Montpellier (J Bousquet, P Demoly); Germany. Hamburg (K Richter); USA: Portland (M Osborne, S Buist, W Vollmer, L Johnson).

\section{APPENDIX 1: QUESTIONS IN THE ECRHS SCREENING (STAGE I) QUESTIONNAIRE}

1. Have you had wheezing or whistling in your chest at any time in the last 12 months? If "no" go to question 2, if "yes":

1.1. Have you been at all breathless when the wheezing noise was present?

1.2. Have you had this wheezing or whistling when you did not have a cold?

2. Have you woken up with a feeling of tightness in your chest at any time in the last 12 months?

3. Have you been woken by an attack of shortness of breath at any time in the last 12 months?

4. Have you been woken by an attack of coughing at any time in the last 12 months?

5. Have you had an attack of asthma in the last 12 months?
6. Are you currently taking any medicine (including inhalers, aerosols or tablets) for asthma?

7. Do you have any nasal allergies including hay fever?

In ECRHS I questions 2, 3 and 7 were omitted or had different wording in the Danish questionnaire. In ECRHS II questions 2, 4 and 7 were omitted in the Spanish questionnaire, question 4 in the Italian questionnaire.

\section{REFERENCES}

1 Prescott-Clarke P, Primatesta P, eds. Health survey for England. 1995 Volume I: Findings. London: The Stationery Office, 1997:24-5.

2 Burney PG, Britton JR, Chinn S, et al. Descriptive epidemiology of bronchial reactivity in an adult population: results from a community study. Thorax 1987;42:38-44.

3 Magder LS, Hughes JP. Logistic regression when the outcome is measured with uncertainty. Am J Epidemiol 1997; 146:195-203.

4 Wolfe R, Carlin JB, Patton GC. Transitions in an imperfectly observed binary variable: depressive symptomatology in adolescents. Stat Med 2003;22:427-40

5 Burney PG, Luczynska C, Chinn S, et al. The European Community Respiratory Health Survey. Eur Respir J 1994;7:954-60.

6 The European Community Health Survey Steering Committee. The European Community Respiratory Health Survey II. Eur Respir J 2002;20:1071-9.

7 StataCorp. Stata Statistical Software: Release 7.0. College Station, TX: Stata Corporation, 2001.

8 DerSimonian R, Laird N. Meta-analysis in clinical trials. Control Clin Trials 1986;7:177-88.

9 Burney PG, Laitinen LA, Perdrizet S, et al. Validity and repeatability of the IUATLD (1984) bronchial symptoms questionnaire: an international comparison. Eur Respir J 1989;2:940-5.

10 Devereux G, Hendrick DJ, Stenton SC. Perception of respiratory symptoms after methacholine-induced bronchoconstriction in a general population. Eur Respir J 1998;12:1089-93.

11 Speight ANP, Lee DA, Hey EN. Underdiagnosis and undertreatment of asthma in childhood. BMJ 1983;286:1253-6.

12 Burney PG, Chinn S, Rona RJ. Has the prevalence of asthma increased in children? Evidence from the national study of health and growth 1973-86. BMJ 1990;300:1306-10.

13 Ninan TK, Russell G. Respiratory symptoms and atopy in Aberdeen schoolchildren: evidence from two surveys 25 years apart. BMJ 1992;304:873-5.

14 Brogger J, Bakke P, Eide GE, et al. Long-term changes in adult asthma prevalence. Eur Respir J 2003;21:468-72.

15 Verlato G, Corsico A, Villani S, et al. Is the prevalence of adult asthma and allergic rhinitis still increasing? Results of an Italian study. J Allergy Clin Immunol 2003;111:1232-8.

16 Barraclough R, Devereux G, Hendrick DJ, et al. Apparent but not real increase in asthma prevalence during the 1990s. Eur Respir $J$ 2002;20:826-33.

17 Eagan TML, Bakke PS, Eide GE, et al. Incidence of asthma and respiratory symptoms by sex, age and smoking in a community study. Eur Respir J 2002; 19:599-605.

18 Toren K, Hermansson B-A. Incidence rate of adult-onset asthma in relation to age, sex, atopy and smoking: a Swedish population-based study of 15813 adults. Int J Tuberc Lung Dis 1999;3:192-7.

19 Dodge RR, Burrows B. The prevalence and incidence of asthma and asthmalike symptoms in a general population sample. Am Rev Respir Dis 1980;122:567-75.

20 Basagaňa X, Sunyer J, Zock J-P, on behalf of the Spanish Working Groups of the European Community Respiratory Health Survey, et al. Incidence of asthma and its determinants among adults in Spain. Am J Respir Crit Care Med 2001; 164:1133-7.

21 Strachan DP, Butland BK, Anderson HR. Incidence and prognosis of asthma and wheezing illness from early childhood to age 33 in a national British cohort. BMJ 1996;312:1195-9.

22 Barbee RA, Kaltenborn W, Lebowitz MD, et al. Longitudinal changes in allergen skin test reactivity in a community population sample. J Allergy Clin Immunol 1987;79:16-24

23 Oryszcyn M-P, Annesi I, Neukirch F, et al. Longitudinal observations of serum $\mathrm{lgE}$ and skin prick test response. Am J Respir Crit Care Med 1995; 151:663-8. 